\title{
Knowledge, Attitudes and Practices on Breast Self-Examination of Students in the Health Area of Two Universities in the City of Cartagena
}

\author{
Jacqueline Hernández-Escolar ${ }^{1}$, Irma Yolanda Castillo-Ávila ${ }^{2}$, Eliana Meza-Montalvo ${ }^{1}$ \\ Regina Domínguez-Anaya ${ }^{3} \&$ Luis Alvis-Estrada ${ }^{2}$ \\ ${ }^{1}$ Health and Social Practices Research Group, Grupo de Investigación Salud y Prácticas Sociales-SYPRES, \\ Universidad de San Buenaventura, Cartagena, Colombia \\ ${ }^{2}$ Health Care of Collectives Research Group, Grupo de investigación Cuidado de la salud de Colectivos, \\ Universidad de Cartagena, Colombia \\ ${ }^{3}$ Human Movement and Health Research Group, Grupo de Investigación Movimiento Humano y Salud-GIMHUS, \\ Universidad de San Buenaventura, Cartagena, Colombia \\ Correspondence: Jacqueline Hernandez -Escolar, Universidad de San Buenaventura, Cartagena, Calle Real de \\ Ternera No.30-966 - PBX 653 5555, Cartagena, Colombia. E-mail: jhernandez@usbctg.edu.co
}

Received: July 25, 2019 Accepted: October 1, 2019 Online Published: October 11, 2019

doi:10.5539/gjhs.v11n12p137 URL: https://doi.org/10.5539/gjhs.v11n12p137

\begin{abstract}
Objective: To determine the knowledge, attitudes and practices on the self-examination of university students in the health area of the universities of the city of Cartagena.

Materials and Methods: descriptive study, 415 students over 20 years old from the health of two universities of Cartagena participated, a multistage sampling was used, first a stratification was done for each university and health area program and then for semesters of universities with proportional fixation. The information collected was stored in Microsoft Excel 10 spreadsheet and analyzed using the statistical package SPSS 24.
\end{abstract}

Results: In the assessment of knowledge, attitudes and practices on breast self-examination, it was found that $82.4 \%$ of the surveyed population knows how it is performed, $95.9 \%$ consider that self-examination is good, but only $74.5 \% \%$ has been done.

Conclusion: Most of the students have good knowledge about breast self-examination, and a favorable attitude toward this procedure, however they do not do it properly, why they do not do it as often or at the right time.

Keywords: attitudes, breast neoplasms, breast self-examination, the health of women students of the Department of Health, practices, knowledge

\section{Introduction}

Breast cancer is one of the neoplasms that generates more impact worldwide, due to its high prevalence, it affects all women regardless of age, race, or social status, it is common both in developed countries and in those that are in the process of development (Publications, National Institute of Cancerology, 2012). According to data from the World Health Organization (WHO), this neoplasm is the leading cause of death from malignant tumors in women, in Latin America approximately 152 thousand cases are diagnosed per year, of which about $15 \%$ are diagnosed in advanced stages (Breast cancer: prevention and control, 2016).

In Latin American countries, Mexico occupies the first place in incidence of malignant neoplasms in women, it represents $11.34 \%$ of all cancer cases and there is an overall increase of approximately $1.5 \%$ per year (Arce et al., 2011). Colombia is no stranger to this situation, according to high-cost data, in 2016 breast cancer ranked first among malignant tumors more frequent in the general population, there were 3954 new cases and 2055 women died from the same cause (Cuentas de alto costo, 2017). Concerning the city of Cartagena, in 2015 this neoplasm occupied the first place among malignant tumors in women, followed by malignant tumors from other locations; presenting a ratio of 11.3 deaths per 100,000 women (Minsalud, 2016).

Breast cancer treatments are based on surgery, chemotherapy and radiotherapy; although improvements are being 
made in these procedures, mortality from breast cancer continues to increase, which is why it is necessary to carry out health education and breast cancer prevention, aiming to get an early diagnosis on of this pathology that guarantees an opportune treatment and a better rehabilitation; aspects that positively influence the quality of life of women suffering from this disease (Moodi, Baladi, Reza, Shahnazi, \& Sharifzadeh, 2011).

This is why WHO promotes comprehensive control of cancer, including prevention, early detection, diagnosis and treatment, rehabilitation and palliative care, and recommends breast self-examination (BSE), clinical examination and mammography, although the BSE is not a method for diagnosing cancer, it has been observed that it is a practice that empowers women, and makes them responsible for their own health, which can lead to the possibility of making an early detection of alterations (Arce et al., 2011).

Breast self-examination is recommended after 20 years of age. This has an extraordinary value because it is the first resource that a woman has to reach an early diagnosis of some pathological processes of the mammary gland and specifically cancer; more than $80 \%$ of breast nodules are diagnosed by the woman herself. (Sardiñas Ponce, 2009). The health professional who work in Primary Care should not be limited to only providing information about the proper practice of the BSE to women, but to show the correct technique to perform it, in addition to supervising that it is performed correctly (Hernández et al., 2014)

Despite the multiple strategies for promoting this practice, the implementation of the BSE has not been totally effective, because there have been difficulties in disseminating its importance (Menéndez, Hidalgo, \& Frómeta, 2011). Data reported by the National Survey of Demography and Health (ENDS) $201593.9 \%$ percent of the women surveyed have information about the BSE, and of these $37.7 \%$ do so on a monthly basis; the knowledge and the regular practice of this screening were better in women living in the urban area, single and with higher education (Profamilia, 2015).

The realization of this practice requires that women have a commitment to their health and care, here the culture and educational level they have play a very important role, it is considered that the university education provides sufficient information to claim that breast self-examination is known, but this level of knowledge does not imply that it is the best, since although they know the importance of the technique they show disinterest in their performance, taking refuge in reasons with little validity (Páez et al., 2010). This was evidenced in the study carried out by medical students where $89.7 \%$ of the participants had heard about this technique, but only $21.0 \%$ practiced it correctly (Carrillo et al., 2015). Bohórquez, meanwhile, evaluated the practice of the BSE in Nursing students from the city of Cartagena, Colombia, where it was evident that $75.8 \%$ of the students practice breast self-examination, but only $2 \%$ of them have all the characteristics of a proper practice, such as monthly frequency, palpation and observation of breasts (Bohorquez, Castillo, \& Montalvo, 2017).

Studying the knowledge, attitudes and practices on breast self-examination is of great interest, especially in health students, who are receiving training to promote the health of the population and these components need to be well-established. that can carry out education about the importance of the BSE as a principal measure for the timely diagnosis of breast cancer, so the evaluation of knowledge, attitudes and practices towards this test in students of the health area can be determinant in the influence of education on the lifestyles of its students, and in turn will allow to undertake strategies at the institutional level in favor of the prevention of breast cancer as a public health priority. Therefore, it was proposed to determine the knowledge, attitudes and practices on breast self-examination of students in the health area of two universities in the city of Cartagena.

\section{Methods}

Descriptive study, 415 students from the area of health, over 20 years old, of two universities of the city of Cartagena participated. A stratified sampling was performed by each university and program in the area of health, with proportional fixation for each semester. Minors and students with a previous diagnosis of breast diseases, with mental illness or cognitive disorders were excluded from the study.

A sociodemographic survey was used to collect the information in order to characterize the participating women, in addition the instrument proposed by Saenz A and Sánchez Á was used to measure the knowledge, attitudes and practices of breast self-examination in women of 15-45 years (Saenz \& Sánchez, 2011). Knowledge was measured through questions with only one answer option (YES, NO, DON'T KNOW). Attitudes were evaluated through a series of statements in which the woman will mark with an X if she TA: Totally agrees; A: Agrees; U: Undecided; D: Disagreement; SD: Strongly disagree. These practices were measured by means of open questions with several response options. This survey has been used by several authors in similar populations, was subject to validity of content by experts in the field for being a CAP survey and applied after a pilot test. The students were approached in the university spaces, before or after the academic activities, the survey was self-administered and was applied 
after signing the informed consent.

The data obtained were stored in a matrix of the Microsoft Excel program and analyzed using the statistical package SPSS version 24. Descriptive statistics were applied to the data, calculating averages, standard deviations and variable proportions for each study.

This research was based on Resolution 008430 of 1993 of the Ministry of Health of Colombia, where it was classified as a minimum risk investigation for the participants, since the measuring instruments employ research techniques and methods that do not perform any intervention or intentional modification of the biological, physiological, psychological or social variables of the individuals participating in the study (Minsalud, 1993). In addition, the research was endorsed by the ethics committee of the University of San Buenaventura Cartagena.

\section{Results}

Table 1. Sociodemographic characteristics from students of the health area of two universities of the city of Cartagena

\begin{tabular}{lcc}
\hline College & $\mathbf{N}$ & $\mathbf{\%}$ \\
\hline A & 248 & 59.8 \\
B & 167 & 40.2 \\
\hline Socioeconomic level & $\mathbf{N}$ & $\mathbf{\%}$ \\
\hline 1 & 92 & 22.2 \\
2 & 142 & 34.2 \\
3 & 123 & 29.6 \\
4 & 31 & 7.5 \\
5 & 13 & 3.1 \\
6 & 5 & 1,2 \\
NA & 9 & 2.2 \\
\hline Semester & $\mathbf{N}$ & $\mathbf{\%}$ \\
\hline 1 & 14 & 3,4 \\
2 & 27 & 6.5 \\
3 & 27 & 6.5 \\
4 & 29 & 7.0 \\
5 & 54 & 13.0 \\
6 & 42 & 10.1 \\
7 & 96 & 23,1 \\
8 & 47 & 11.3 \\
9 & 47 & 11.1 \\
10 & 32 & 7.7 \\
NA & 1 & 0.2 \\
Total & 415 & 100 \\
\hline
\end{tabular}

The study included 415 health students, over 20 years of age, belonging to two universities in Cartagena, with an average age of 21.9 years $(\mathrm{SD}=2.5)$, respectively. In relation to the socioeconomic level, level 2 predominated in $34.2 \%$, followed by level 3 in $29.6 \%$ and a minimal proportion in level $6(1.2 \%)$. With regard to the academic level in which they are found, $23.1 \%$ are in the seventh semester of the university program they are following (Table 1).

Table 2. Knowledge of breast self-examination in students of the health area of two universities in the city of Cartagena 


\begin{tabular}{llc}
\hline Do you know how the BSE is done? & N & $\mathbf{\%}$ \\
\hline Yes & 342 & 82,4 \\
No & 65 & 15,7 \\
Doesn't know & 8 & 1.9 \\
\hline Who should perform the BSE? & $\mathbf{N}$ & $\mathbf{\%}$ \\
\hline All women & 151 & 36.3 \\
All women older than 20 years old & 260 & 62.7 \\
Only women with active sexual life & 1 & 2 \\
NA & 3 & 0.7 \\
\hline What is the BSE for? & $\mathbf{N}$ & $\mathbf{\%}$ \\
\hline For what is done to detect cancer & 281 & $67.7 \%$ \\
Search for a disease & 125 & $30.1 \%$ \\
Be sure to be healthy & 159 & $38.3 \%$ \\
Know if you are okay & 82 & $19.8 \%$ \\
Know your body & 46 & $11.1 \%$ \\
\hline At what time should the BSE be performed? & $\mathbf{N}$ & $\mathbf{\%}$ \\
\hline Every fifteen days & 36 & 8.6 \\
Each month & 190 & 45.8 \\
Every two months & 57 & 13.8 \\
Approximately one week after menstruation & 123 & 29.6 \\
NA & 9 & 2.2 \\
Total & 415 & 100.0 \\
\hline
\end{tabular}

Regarding the knowledge about breast self-examination, $82.4 \%$ know how to perform this procedure, $62.7 \%$, affirms that all women from the age of 20 must practice it. $67.7 \%$ think that the BSE is done to detect cancer; $45.8 \%$ stated that it should be done with a monthly frequency and $29.6 \%$ thought that it should be done approximately one week after menstruation (Table 2).

Table 3. Attitudes of breast self-examination in students of the health area of two universities in the city of Cartagena

\begin{tabular}{|c|c|c|c|c|c|c|c|c|c|c|}
\hline PROPOSITIONS & SA & $\%$ & $\mathbf{A}$ & $\%$ & $\mathbf{U}$ & $\%$ & DS & $\%$ & DK/A & $\%$ \\
\hline It is good to do it & 398 & 95.9 & 15 & 3.6 & 2 & 0.5 & 0 & 0.0 & 0 & 0.0 \\
\hline $\begin{array}{l}\text { I perform breast self-examination to protect myself } \\
\text { from diseases }\end{array}$ & 224 & 54.0 & 134 & 32.3 & 27 & 6.5 & 22 & 5.3 & 8 & 1.9 \\
\hline Breast self-examination gives me many benefits & 265 & 63.9 & 124 & 29.9 & 20 & 4.8 & 5 & 1,2 & 1 & 0.2 \\
\hline $\begin{array}{l}\text { Health personnel influences the performance of the } \\
\text { exam }\end{array}$ & 157 & 37.8 & 175 & 42.2 & 50 & 12.0 & 25 & 6.0 & 8 & 1.9 \\
\hline $\begin{array}{l}\text { In young women, the practice of breast } \\
\text { self-examination is not so important. }\end{array}$ & 31 & 7.5 & 22 & 5.3 & 64 & 15.4 & 297 & 71.6 & 1 & 0.2 \\
\hline I worry about the appearance of lumps or other & 309 & 74.5 & 76 & 18.3 & 8 & 1.9 & 21 & 5.1 & 1 & 0.2 \\
\hline It is a sin to perform it & 21 & 5.1 & 8 & 1.9 & 11 & 2.7 & 373 & 89.9 & 2 & 0.5 \\
\hline Religion influences the decision to take the test & 25 & 6.0 & 14 & 3,4 & 40 & 9.6 & 329 & 79.3 & 7 & 1.7 \\
\hline Breast cancer can be detected early and cured by breast & 284 & 68.4 & 76 & 18.3 & 22 & 5.3 & 33 & 8.0 & 0 & 0.0 \\
\hline
\end{tabular}




\begin{tabular}{|c|c|c|c|c|c|c|c|c|c|c|}
\hline \multicolumn{11}{|l|}{ self-examination } \\
\hline $\begin{array}{l}\text { Breast self-examination does not help early detection of } \\
\text { breast cancer }\end{array}$ & 72 & 17.3 & 45 & 10.8 & 38 & 9.2 & 258 & 62.2 & 2 & 0.5 \\
\hline $\begin{array}{l}\text { I can go to a healer to give me massages and remedies to } \\
\text { cure me }\end{array}$ & 8 & 1.9 & 10 & 2,4 & 19 & 4.6 & 377 & 90.8 & 1 & 0.2 \\
\hline I do not have time to do it & 14 & 3,4 & 3.4 & 8.2 & 54 & 13.0 & 311 & 74.9 & 2 & 0.5 \\
\hline I feel lazy & 14 & 3,4 & 37 & 8.9 & 58 & 14.0 & 304 & 73.3 & 2 & 0.5 \\
\hline I forget it & 41 & 9.9 & 87 & 21.0 & 52 & 12.5 & 232 & 55.9 & 3 & 0.7 \\
\hline I do not think it's important & 12 & 2.9 & 11 & 2.7 & 14 & 3,4 & 374 & 90.1 & 4 & 1.0 \\
\hline The health staff has not explained to me about this & 42 & 10.1 & 74 & 17.8 & 54 & 13.0 & 245 & 59,0 & 0 & 0.0 \\
\hline
\end{tabular}

SA: Strongly agree, A: agree, U: undecided, Ds: disagree, SDS: strongly disagree; DK / NA: Do not know/No answer.

In relation to the attitudes of the participants towards breast self-examination, $95.9 \%$ think it is good to perform self-examination; $63.9 \%$ consider that this screening gives many benefits to their health; $68.4 \%$ consider that breast cancer can be detected early by carrying out the BSE; It should be noted that there is a significant percentage of students who state that health personnel have not explained this procedure to them with $10.1 \%$; also that $3.4 \%$ forget or are too lazy to do it (Table 3).

Table 4. Practice of self-examination breast in students of the health area of two universities of the city of Cartagena

\begin{tabular}{lcc}
\hline Have you ever been told about self-examination in your consultations? & N & $\%$ \\
\hline Yes & 177 & 42.7 \\
No & 238 & 57,3 \\
\hline Who has explained to you about breast self-examination? & $\mathbf{N}$ & $\mathbf{\%}$ \\
\hline Nurse & 61 & 15 \\
Nurse and doctor & 10 & 2 \\
Doctor & 162 & 39 \\
Does not respond & 77 & 19 \\
Other & 105 & 25 \\
\hline Have you performed Breast Self-Examination before? & $\mathbf{N}$ & $\%$ \\
\hline Yes & 311 & 74.5 \\
No & 104 & 25.5 \\
\hline
\end{tabular}

As far as the practice of breast self-examination is concerned; $57.3 \%$ of the participants have not explained in the consultations how this procedure is performed, the professional who has explained about this procedure is the doctor in $39 \%$ of the cases and the nursing professionals in $15 \%$, it should be noted that $25 \%$ of the participants state that they have received the information from other sources; as family, friends or television. It was also identified that only $49 \%$ of the participants had previously undergone breast self-examination (Table 4). 
Table 5. Frequency and technique of breast self-examination in students of the health area of two universities in the city of Cartagena

\begin{tabular}{|c|c|c|}
\hline How often is it done? & $\mathbf{N}$ & $\%$ \\
\hline Twice a month & 55 & 17.7 \\
\hline Once a month & 248 & 78.5 \\
\hline Does not know & 8 & 2.6 \\
\hline What day of the month is the breast self-exam done? & $\mathbf{N}$ & $\%$ \\
\hline 15 days after the last menstruation & 86 & 27.7 \\
\hline 10 days after the last menstruation & 155 & 49.8 \\
\hline 20 days after the last menstruation & 63 & 20.3 \\
\hline Does not know & 8 & 2.6 \\
\hline Last time the breast self-examination was performed? & $\mathbf{N}$ & $\%$ \\
\hline One month & 122 & 39.2 \\
\hline One week & 52 & 16.7 \\
\hline Two months & 132 & 42.4 \\
\hline Does not know & 5 & 1.6 \\
\hline Arm position for inspection during breast self-examination? & $\mathbf{N}$ & $\%$ \\
\hline Separated and flexed & 39 & 12.5 \\
\hline Separated and extended & 12 & 3.9 \\
\hline Together and flexed & 191 & 61.4 \\
\hline Together and apart & 64 & 20.6 \\
\hline Does not know & 5 & 1.6 \\
\hline How do you examine your breasts? & $\mathbf{N}$ & $\%$ \\
\hline Both at once & twenty & 6.4 \\
\hline One at a time & 282 & 90.4 \\
\hline Does not know & 9 & 2.9 \\
\hline During breast self-examination you should press & $\mathbf{N}$ & $\%$ \\
\hline Strong and with circular movements forming a spiral & 166 & 53.4 \\
\hline Medium and without circular movements & 133 & 42.8 \\
\hline Gently with circular movements and making concentric circles & 2 & 0.6 \\
\hline Slightly and make circular movements & 2 & 0.6 \\
\hline Does not know & 8 & 2.6 \\
\hline At what age did you start breast self-examination? & $\mathbf{N}$ & $\%$ \\
\hline Before age 14 & 15 & 4.8 \\
\hline From age 14 to 20 & 164 & 52.7 \\
\hline After age 20 & 129 & 41.5 \\
\hline Does not know & 3 & 1.0 \\
\hline Total & 311 & 100.0 \\
\hline
\end{tabular}

Of the 311 students who have done breast self-exam, only $78.5 \%$ do it every month; $49.8 \%$ practice it from the fourth to the tenth day from the first day of menstruation.

$16.7 \%$ of the participants said they had undergone breast self-examination a month ago, while $42.4 \%$ two months 
ago. Regarding the technique, 90.4\% examined one breast at a time, and made a strong pressure with circular movements forming a spiral $53.4 \%$. Regarding the age of beginning of this $52.7 \%$ did it between 14 and 20 years and only $41.5 \%$ after 20 years. (Table 5)

\section{Discussion}

Breast self-examination is a practice empowers women about their self-care and health care, which leads to a timely detection of breast changes, also allows for early treatment opportunities and minimize the consequences in people who suffer the alteration (Páez et al., 2010).

In the present study it was evident that most of the women belonged to socioeconomic level 2, and a minimal proportion level 6, results that agree with those found by Bohórquez in Cartagena, where the socioeconomic level that predominated was 2 with a $43.1 \%$ and in lower prevalence the level 5 with $0.7 \%$ (Sáenz \& Sánchez, 2011). According to the ENDS 2015 results, women who had a higher wealth index had a better practice of breast self-examination, this may be because these people have greater access to health services (Profamilia, 2015).

Regarding the level of training, students were at advanced levels of the university career, a higher educational level is considered as a protective factor in the health of people, because there is more awareness of self-care (Gomes et al., 2012; Ricardo \& Fernández, 2006) compared the knowledge of university and non-university students, found some influence of higher education in the knowledge they may have about breast self-examination, because in the university students group generally knew it and in the non-university one the proportion of those who knew it was not significant, which means that the fact that a woman has access to education and training means that she has tools to detect early changes in the breast.

Regarding the knowledge about breast self-examination, it was identified that a large part of the women surveyed said they knew how breast self-examination is performed and that all women must perform it after age 20, results that are related to what Gutiérrez obtained in Bolivia, where $80.2 \%$ of medical students state that they know about breast self-examination and also consider that the age to begin breast self-examination is before age 20 (Gutiérrez et al., 2012). Knowledge is considered as the basis for the development of the practices that people have, when this information is clear and complete the result that is obtained is very likely to be appropriate, that is why it is expected that knowledge about health care generates a better attitude and an adequate practice of breast self-examination in students in the health area who have it (Parra \& Efraín, 2015).

Regarding attitudes about breast self-examination, it was found that they have a favorable attitude to carry out this practice, stating that carrying out this practice can bring health benefits (Gutiérrez et al., 2012). It was evidenced that all the students of the medical school had a positive attitude towards self-examination. It was evidenced that a percentage of students say that they forget to perform breast self-exam or they are lazy Similar results were found in the research carried out in the city of Tunja (Ospina et al., 2011). Where the main barriers encountered were not having received information, they forgot the procedure and did not consider it important.

With regard to the practice of breast self-examination, it was found that the majority of university students have previously performed breast self-exams. The above differs from what was found by Rodrigo M, in his study of medical students in Lima whose percentage of those who did it was low. In his study conducted to medical students in Lima whose percentage of those who did it was low. Of those who practice it in this study, most women do not use an appropriate technique because they do not place their fingers in the correct position, they examine both breasts at the same time, the movements are with a medium pressure and without circular movements, which indicates that the technique used for the inspection and palpation of the breast was inadequate as established in the technical standard for the early detection of breast cancer (Ospina et al., 2011).

Regarding the frequency of breast self-examination, it is evident that the students perform breast self-exam at inappropriate times of the menstrual cycle, as evidenced by (Bohórquez, Montalvo, \& Castillo, 2017) where only a small proportion of the participants perform breast self-examination between the fourth and the tenth day after the first day of menstruation, as recommended by the technical standard for detection of early breast cancer Carrying out the breast self-examination at inappropriate times of the menstrual cycle exposes the woman to find abnormalities derived from the hormonal changes, which can turn into false positives.

The university students of the health area of two universities of Cartagena possess the knowledge and a favorable attitude about breast self-examination but, they have an inadequate practice of this procedure, even having the knowledge that is imparted from their professional academic formation. Due to this, it is necessary that the professional personnel in charge of the programs of health promotion and disease prevention strengthen the practice of breast self-examination as an instrument for the timely detection of some anomaly in the breast through continuing education provided by the professional in charge of leading the program to the university students 
providing them with timely information and simulations of a correct practice on breast self-examination.

These results become an alert for higher education institutions, which provide health programs, since strategies must be created for better training of students and future health professionals who will become agents of change in the population.

\section{Funding}

This research was funded by the University of San Buenaventura Cartagena and the University of Cartagena.

\section{Competing Interests Statement}

The authors declare that there are no competing or potential conflicts of interest.

\section{References}

Análisis de la situación de salud con el modelo de determinantes sociales de salud del Distrito de Cartagena de Indias. (2016). $\quad$ Retrieved from https:/www.minsalud.gov.co/sites/rid/Lists/BibliotecaDigital/RIDE/VS/ED/PSP/asis-distrital-2016-cartage na.pdf

Arce, C., Bargalló, E., Villaseñor, Y., Gamboa, C., Lara, F., Pérez, V., \& Villarreal, P. (2011). Cancer de Mama. Retrieved from http://incan- exico.org/revistainvestiga/elementos/documentosPortada/1327324685.pdf

Bohórquez C, Montalvo A, Castillo I. (2017). Autoexamen de mama en estudiantes de enfermería de Cartagena, Colombia. Archivos De Medicina (Manizales), 17(2), 361. https://doi.org/10.30554/archmed.17.2.2040.2017

Breast cancer: Prevention and control (2016, January 21). Retrieved April 1, 2018, from http://www.who.int/cancer/detection/breastcancer/en/

Cuenta de alto costo. Boletín de Información técnica especializada. Cáncer de mama. (2017, 19 de octubre) Retrieved from https://cuentadealtocosto.org/site/images/Boletin_Dia_Mundial_cancer_de_mama.pdf

Carrillo, R., Espinoza, M., Avilez, J., \& Osada, J. (2015). Nivel de conocimiento y frecuencia de autoexamen de mama en alumnos de los primeros años de la carrera de Medicina. Revista Médica Herediana, $26(4), 209$. https://doi.org/10.20453/rmh.v26i4.2699

Gutiérrez, A., Rupher, F., Gutiérrez, J., Guzmán, F.., \& Santander, A. (2012). Conocimiento, actitud y práctica del autoexamen mamario en mujeres estudiantes de medicina de la Universidad Mayor de San Simón Gestión 2011. Revista Cientifica Ciencia Médica, 15(2), 22-25. Retrieved from http://www.redalyc.org/pdf/4260/426041225006.pdf

Hernández, Y., Izquierdo, A., González, W., \& Chávez, M. (2014). Costos y beneficios del examen de mama: consultorio No. 9, Policlínico Universitario Pedro Borrás Astorga. Retrieved from http://galeno.pri.sld.cu/index.php/galeno/article/view/201/125

Menéndez, G., Gilberto, E., Hidalgo, R., Yusleidys, \& Frómeta Martínez, A. M. (2011). Acciones instructivas en mujeres con riesgo de padecer cáncer de mama. Revista Cubana de Obstetricia y Ginecología, 37(4), 541-550. Retrieved from http://scielo.sld.cu/scielo.php?script=sci_arttext\&pid=S0138-600X2011000400011\&lng= es\&tlng=es

Ministerio de Salud y Protección social. (2012). Instituto Nacional de cancerología. Hechos \& acciones. Retrieved from https://www.cancer.gov.co/publicaciones

Moodi, M., Baladi, M., Reza, G., Shahnazi, H., \& Sharifzadeh, G. (2011). Evaluation of breast self-examination program using Health Belief Model in female students. Retrieved from https://www.ncbi.nlm.nih.gov/pmc/articles/PMC3214340/

Ospina D, J., Manrique-Abril, F., Vega, N., Morales Pacheco, A., \& Ariza R, N. (2011). La no realización del autoexamen de mama en Tunja, Colombia. Enfermería Global, 10(3). https://doi.org/10.4321/S1695-61412011000300003

Páez, Á., Urrea, E., Contreras, M.., \& Díaz, M. (2010). Conocimiento y frecuencia de los factores de riesgo para cáncer de mama en las estudiantes del área de la salud. Investigación en Enfermería: Imagen Y Desarrollo, 12(2), 25-36. Retrieved from https://revistas.javeriana.edu.co/index.php/imagenydesarrollo/article/view/1153

Parra, O., \& Efraín, F. (2015). Conocimientos, actitudes y prácticas del autoexamen de mamas en mujeres del área rural. Cuenca, 2014. (Tesis para optar título de especialista) Retrieved from 
http://dspace.ucuenca.edu.ec/handle/123456789/21207

Profamilia (2015). Encuesta Nacional de Demografia y Salud. Retrieved from http://www.profamilia.org.co/docs/TOMO\%20II.pdf

Resolución N 008430 (1993). Ministerio de salud. Por la cual se establecen las normas científicas, técnicas y administrativas para la investigación en salud. (2019). Retrieved from https://www.minsalud.gov.co/sites/rid/Lists/BibliotecaDigital/RIDE/DE/DIJ/RESOLUCION-8430-DE-199 3.pdf

Ricardo, W., \& Fernández, A. (2006) Autoexamen de Mamas: Influencia de la educación universitaria en la realización del autoexamen de mamas. Rev. de Posgrado de la VI Cátedra de Medicina, (159), 1-7

Sáenz, A., \& Sánchez, A. (2011). Conocimientos, actitudes y prácticas del autoexamen de mama en mujeres de 15 - 45 años que acuden a los consultorios de Planificación Familiar y Papanicolaou del Hospital Nacional Daniel Alcides Carrión, periodo agosto -diciembre del 2010 (Tesis Doctoral). Retrieved from http://cybertesis.unmsm.edu.pe/bitstream/cybertesis/3012/1/saenz_oa.pdf

Sardiñas Ponce, R. (2009). Autoexamen de mama: un importante instrumento de prevención del Cáncer de mama en atención primaria de salud. Revista Habanera de Ciencias Médicas, 8(3). Retrieved from http://scielo.sld.cu/scielo.php?script=sci_arttext\&pid=S1729-519X2009000300005\&lng=es\&tlng=es

Xavier Gomes, L., Conceição Alves, M., Barbosa Santos, T., de Andrade-Barbosa, T., \& de Souza Leite, M. (2012). Conhecimento e prática do autoexame das mamas por acadêmicas de enfermagem. Revista Cubana De Enfermería, 28(4). Retrieved from http://revenfermeria.sld.cu/index.php/enf/article/view/120

\section{Copyrights}

Copyright for this article is retained by the author(s), with first publication rights granted to the journal.

This is an open-access article distributed under the terms and conditions of the Creative Commons Attribution license (http://creativecommons.org/licenses/by/4.0/). 